Following chapters deal with selenium, cobalt, iodine and fluorine; all of these are essential to animals and cobalt is essential for leguminous plants. There are brief accounts of the possible effects on plants and animals of nickel, lithium, vanadium, silicon and aluminium.

The text is concluded with a bricf but wisc discussion on correcting trace element deficiencies, and tho possibilities of incorporating them into mixed fertilizers supplying major nutrients. Sauchelli did not recommend "shotgun" applications where deficiencics had not been diagnosed. There is a list of commercial American producers of trace elements and methods of analysis are briefly described.

It is a relatively short book, but sufficient for agricultural students and it is recommended to them. Advisers and research workcrs with trace element problems will have use for the accounts of deficiencies and rnethods of correcting them. Further information can be got from the numerous references. Sauchelli read widely and European literature is well represented in the bibliographies (this is rot always so in American books on agricultural science). The book is well printed, but the black-and-white illustrations of deficient plants are little holp (there are no colour plates). It is very expensive and the price will prohibit purchase by many who would find it useful.

G. W. Cooke

\section{COMPARTMENTAL ANALYSIS}

Multicompartment Models for Biological Systems

By G. L. Atkins. (Methuen's Monographs on Biological Subjects.) Pp.xiii + 153. (Methuen: London, November 1969.) 35s.

WHEN a substance such as a radioactive tracer is introduced into a biological system, its concentration in any particular part of the system may first rise and thereafter declines asymptotically to a steady level, which may be zoro. Such a curve can usually be fitted empiricully by super-position of a few exponential components. This, as it happens, is exactly the behaviour of a tracer in a system consisting of a number of well mixed pools or compartments which interchange material with each other at a constant rate; the number of exponential compononts is one fewer than the number of compartments (which may possibly include the external environment). Compartmental analysis consists in the derivation of concentration curves for various models and conversely in the devising of models to fit experimental concentration curves. There is a temptation to identify the compartments arising from the analysis with the recognizable anatomical divisions of the biological system. This identification, however, is open to the objection that there is very great latitude in fitting functions to a set of experimental points subject to even moderate error. Given a priori linowledge of the number of compartments there is very great imprecision in determining the size and exchange rate of any one of them. Moreover, there is seldom any guarantee that an anatomical division behaves as a single homogeneous compartment, and even if one component more than the minimum required to achieve a satisfactory fit is introduced, the range of possible combinations of functions is further enormously increased.

These considerations, which a little experiment will easily verify, might well cause a reader to doubt whether the process of compartmental analysis is of any scientific value, and if he approached Dr Atkins's book in this frame of mind, he would find little to dispel his scepticism. This is the weaknoss of the book; it deals too briefly with the very matter for which there is the greatest need, the appraisal of the validity of the solutions obtained. The chapter on treatment of experimental data and curve fitting is decidedly thin. In fairness to the author, however, a really adequate treatment would need to be quite elaborate, possibly too elaborate for the audience ho has in mind.

The book does not attempt a formal exposition of the subject, such as is already available in essence in the usual texts on differential equations; it is rather a survey of the techniques of compartmental analysis and of their fields of application. This is supported by a fairly extensive and woll chosen bibliography. A non-rigorous mathematical treatmont is introduced as required, with a brief treatment of the differential operator, D, and of the Laplace transform given as an appendix. This approach will probably be congenial to a reader with some mathematical equipment who wishes to comprehend the general mathematical strategy without actually becoming expert himself. Such a reader will bo glad of the chapter on simulation techniques in which methods of obtaining analogue representatives are described. The use of digital computers is only touched on, but sufficient references are given to lead the reader towards the holp he may need.

E. W. EMERY

\section{TISSUE INCOMPATIBILITY}

\section{Immunogenetics of Tissue Transplantation}

By A. Lengerová. (North-Holland Research Monographs Frontiers of Biology, Volume 16.) Pp. xv +270. (North-Holland: Amsterdam and London, 1969.) Hfl. 45; $126 s$.

As Dr Alena Lengerová explains in her welcome book, immunogenetics used to be thought of largely as the application of immunological techniques to the solution of genetical problems. This is no longer so, for the stidy of tissue and organ transplantation (with its extension into the fields of auto-immunity and tumour immunology is now a science in its own right in which an understanding of the genetical control and inheritance of cellular antigens is of paramount importanco. It is cntirely appropriate that immunogenetics should provide us with such a fine example of hybrid vigour: here, two branches of science converge and interact in the liveliest manner, and we need hardly be surprised that this interaction has been so outstandingly fruitful.

The book arose from a lecture course given by this Czech scientist in 1968 at the University of Indiana and it was never intended to embrace the whole field; it, does not, for example, include, except in passing, the geneties of human blood groups or of allotypic determinants. Instead, the author sticks closely to her brief of analysing the immunogenetics of the cellular antigens responsible for the induction of tissue incompatibility, and this she does superbly well. It seems nevertheless surprising that she has not devoted a chapter to the genetics of human transplantation antigens: although (and perhaps just because) this new branch of immunogenetics is still in a rolativcly rudimentary state it would have been most helpful to the general reader to have had the benefit of Dr Lengerová's guidance and critical appraisal.

The H-2 locus of the mouse-that much studied histocompatibility locus controlling tho appearance of the strongest and therefore, by definition, the most important transplantation antigens-is naturally given pride of place. Dr Lengerová does not scorn a historical account when required, and it is good to bo reminded of how much we owe to the work of the late P. A. Gorer and to G. D. Snell and their colleagues. While never oversimplifying, the authcr frequently finds it necessary (and understandably so) to get down to first principles, and it is this quality of lucid exposition that will make this book a valuable roferenco text, not only for immunologists but also for students of genetics, biology and kindred subjects. When first coming to grips with immunology, students are 